\title{
Control of Tetracycline Residues in Meat Traded in North Sinai Egypt Using Traditional Techniques
}

\author{
Nagwa M.T. El-Sharawy, Ahmed A. M., Soad A. Soliman \\ Dept. of Food Hygiene, Faculty of Vet. Med., Suez Canal University, Egypt
}

\begin{abstract}
Antibiotics residues appear to be the most important chemical hazards in meat. Therefore a total of 330 meat, liver and kidney samples (110 of each) were randomly collected from El-Arish abattoir to evaluate their tetracycline residual content. The samples were divided based on animal age as following; group I, 30 veal ( $<6$ months), group II, 30 bull (7-18 months) and group III, 30 cow (>5 years) age carcasses and group IV, 20 imported frozen meat samples. Positive meat samples for tetracycline were treated using marinating and simmering technique to study their effects on tetracycline levels. Tetracycline residues were not detected in all samples of group I. The mean concentrations of tetracycline values for meat, liver and kidney of group II were 11.296, 15.984 and $21.032 \mu \mathrm{g} / \mathrm{g}$ respectively. Meanwhile for group III were 23.116; 41.255 and $45.022 \mu \mathrm{g} / \mathrm{g}$ and for group IV were 8.596, 12.684 and $16.832 \mu \mathrm{g} / \mathrm{g}$ respectively. All examined samples (100\%) were within the permissible limits sets by the Egyptian Organization for Standardization and Quality Control. Marinating technique significantly reduce $(P<0.05)$ the concentrations level of tetracycline in meat in groups II; III and IV by levels $12.2 \%$; $45.1 \%$ and $11.4 \%$ respectively. Meanwhile, simmering technique significantly reduce $(P<0.05)$ the concentration levels of tetracycline in meat in groups II; III and IV by levels $8.4 \% ; 15.0 \%$ and $6.6 \%$ respectively. Veterinarians must have updated information about the proper withdrawal times of tetracycline used in their areas of practice.
\end{abstract}

\section{Introduction}

Meat is a good source of the all essential nutrients necessary for normal development, growth, repair and proper tissue formation. Hence, human diets should contain at least some meat and or meat products in order to guarantee proper nutrition (Eremong, 2011 and Bala et al,
2012). Although meat forms an important part of the human diet as well as an important source of a wide range of nutrients, they may carry harmful chemical residues. The levels of these harmful residues in meat is generally low if compared to offal such as liver and kidney, which showing higher 
concentration levels than most other foods (Khalafalla et al, 2011).

Antibiotics are substances that kill or inhibit the growth of bacteria which considered broad antibacterial spectrum. The tetracycline, among the first of the antibiotics to become available 50 years ago, are still widely used in Sinai, Egypt. While the quinolones which are divided into two categories one of them is ciprofloxacin are limited used in a large animal $(X u$ et $A l, \quad 2006$; Salehzadeh et al, 2007 and Shareef et. al, 2009).

Abuse using of tetracycline in veterinary practice may leave residues in edible tissues. These residues may have direct toxic effects on consumer. Failure to observe withdrawal period in the different animal species before slaughtering for human consumption may be responsible for residual accumulation in meat particularly when treated with an extra-label dose.

The bioaccumulation of tetracycline in the meat predispose to development of drug resistant bacteria and allergic reactions in consumers (Ibrahim et al, 2010 and Heba, 2012 and Olusola et al, 2013). The study done by Lei et al (2010) founded that more than $70 \%$ of $1030 \mathrm{E}$. coli isolates obtained from southern China abattoir showed a resistance to tetracycline. Regulatory authorities should constantly conduct surveillance to monitor the antibiotic levels in order to safeguard human health. Also, there is no available literatures revealed control mechanism exist to protect the consumers against the consumption of meat containing harmful drug residues. Therefore, the objectives of the current study were to determine the concentration levels of tetracycline in muscle, liver and kidney of cattle. Another aim was to control the tetracycline residues in meat using marinating and simmering technique.

\section{Material and Methods}

Study area: A cross-sectional study was conducted in El-Arish abattoir to determine the concentration levels of tetracycline residues in meat and edible offal. North Sinai Governorate is located in the eastern part of Egypt. Samples have been randomly collected from the slaughterhouse. The chemical analyses were carried out in the Central Laboratory of the Faculty of Veterinary Medicine, Suez Canal University.

Sampling: A total of 330 random samples of meat (rump stick), liver and kidney (110 of each) which were collected from 110 carcasses in El-Arish abattoir and imported meat markets. The samples from local abattoir are divided based on animal age as following; Group I, 30 veal ( $<6$ months), Group II, 30 bull (7-18 months) and Group III, 30 cow ( $>5$ years) age carcasses and 
Group IV, 20 imported frozen meat samples. Each samples weighted from $100 \mathrm{~g} \pm 10$ was rapped in plastic bag then identified and transferred in an ice-box to the laboratory for evaluation.

Qualitative detection of tetracycline by four plate method: Method described by Levetzow and Wise (1979) were used in this study for qualitative detection of antibiotic residues in meat, liver and kidney samples. The positive samples were indicated by measuring the diameter of inhibition zones, more than or equal to $2 \mathrm{~mm}$, of the growth of the Bacillus subtilis around meat samples.

Quantitative detection of tetracycline residues: Method used by high performance liquid chromatography (HPLC) was followed for determination of concentration levels of tetracycline residues in examined samples.

Effect of marinating on chemical residues: $25 \mathrm{~g}$ of positive meat sample for tetracycline residues was marinated using the following formula: $5 \mathrm{~g}$ Egyptian red onion "Allium cepa"; $1 \mathrm{~g}$ commercial Egyptian table salt Iodine free "Alkhair" $5 \mathrm{ml}$ lemon juice "Rutaceae Citrus" and $1 \mathrm{~g}$ black pepper "Piperaceae Nigrium". Meat, samples were kept in marinating formula for 4 hours at $4^{\circ} \mathrm{C}$. Each sample put in a clean bottle, identified and was sent to laboratory for a quantitative evaluation of the concentration levels of tetracycline residues.

Effect of simmering on tetracycline residues: $25 \mathrm{~g}$ of positive meat sample for tetracycline residues was placed into strainer contained $50 \mathrm{ml}$. diionized water then heated to $100^{\circ} \mathrm{C}$ and cooked for 30 minutes then allow to cool. Each sample put in clean bottle, identified and sent to a laboratory for quantitative evaluation of the concentration levels of tetracycline residues.

Statistical Analysis (GraphPad Instant, 2009): The statistical program, Graph Pad Instant version 3 for window, was used for determination of means, the analysis of variance between the different data and treatment in this study was determined using standard error and analysis of variance $(P<0.05)$. Figures were used to display the significant difference at the 5\% level between the obtained results.

\section{Results and Discussion}

Food safety is of paramount importance to the meat industry. Pollution of the environment by antibiotic residues in meat is a serious global problem. The industrial and agricultural development had been responsible for the diffusion of many chemical substances in the environment causing the pollution of the community and atmosphere (Farag, 2002). 
Tetracycline residues in meat

The mean concentration levels for tetracycline residues in meat, liver and kidney samples were presented in table (1). Tetracycline residues were not detected in all samples of group I. It is mainly due to young age of the veal at the time of slaughter. Similar results were reported by Abdul Salam et al (2010) and Basma, (2012).

The mean concentration tetracycline values for meat, liver and kidney of group II were 11.296, 15.984 and $21.032 \mu \mathrm{g} / \mathrm{g} \quad$ respectively. Meanwhile for group III were 23.116; 41.255 and $45.022 \mu \mathrm{g} / \mathrm{g}$ and for group IV were 8.596, 12.684 and $16.832 \mu \mathrm{g} / \mathrm{g}$ respectively. Age of the slaughtered animals had a significant effect $(p>0.05)$ on the concentrations levels of tetracycline in the examined samples. Same results were obtained by Olatoye $\&$ Ehinmowo (2010) and Bedada et al (2012).

Tetracycline is broad-spectrum antibiotics widely used in modern animal husbandry (Dana et al, 2008 and Lama, 2010). Farm animals treated with antibiotics are required to be held for specific withdrawal period until all residues are depleted to safe level before the animal tissue can be used as food for human consumption (KuKanich et $a l, 2005)$. The withdrawal period of tetracycline is seven days, improper therapeutic dosage of tetracycline or slaughter of animal within the withdrawal period can result of sever toxicological, microbiological or immunological problems $(\boldsymbol{F A O}$, 1999).

The Egyptian Organization for Standardization and Quality Control (EOS, 2010, No. 7136) is set a permissible limit for tetracycline residues in meat and offal which must be not exceed than $100 \mu \mathrm{g} / \mathrm{g}$ for meat and $300 \mu \mathrm{g} / \mathrm{g}$ for cattle offal. According to this limit, all examined samples $(100 \%)$ were within the permissible limits and considered safe for human consumption. Therefore, the European Union established the allowable daily intake of tetracycline for humans as 0.003 $\mathrm{mg} / \mathrm{kg}$ (Al-Wabel, 2011; Addisalem et al, 2012 and Basma, 2012).

Effect of Marinating and Simmering Technique on Tetracycline

\section{Residues}

Marinating is the process of soaking meat in a seasoned, often acidic, and liquid before cooking. The effect of marinating technique on concentrations level for tetracycline residues in meat were revealed in table (2). The mean concentrations tetracycline values for marinating meat in groups I, II and IV were 9.915; 12.527 and $7.615 \mu \mathrm{g} / \mathrm{g}$ respectively. Marinating ingredients often contains oils, herbs, and spices to further flavor the food items. It is commonly used to flavor foods and to tenderize tougher cuts of meat (Joanne, 2012; Shirley, 2012 and Wikipedia, 2013). 
Marinating technique significantly reduces $(P>0.05)$ the concentrations level of tetracycline in meat in groups I; II and IV by levels $12.2 \%$; $45.1 \%$ and $11.4 \%$ respectively. The marinating ingredients used in this study, red onion, table salt lemon juice and black pepper, show a significant reduction $(\mathrm{P}>0.05)$ in concentrations levels of tetracycline residues of treated meat.

\section{Effect of Simmering Technique on Tetracycline Residues}

Simmering is a meat preparation technique in which meat are cooked in hot liquids kept at or just below the boiling point of water $\left(100^{\circ} \mathrm{C}\right)$. The effect of simmering technique on concentrations level for tetracycline residues in meat were presented in table (3). The mean concentration tetracycline values for simmering meat in groups I, II and IV were 9.24.894; 34.818 and $22.499 \mu \mathrm{g} / \mathrm{g} \quad$ respectively. Simmering technique significantly reduce $(P>0.05)$ the concentrations level of tetracycline in meat in groups I; II and IV by levels $8.4 \%$; $15.0 \%$ and $6.6 \%$ respectively. The simmering processes show a significant reduction $(P>0.05)$ in

Table (1) Mean Concentrations Level for Tetracycline Residues in Meat, Liver and Kidney Samples

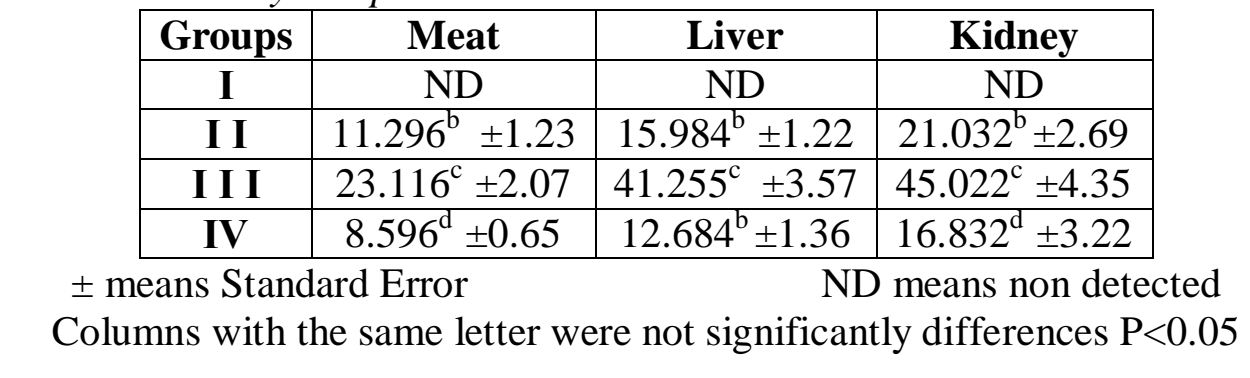

\pm means Standard Error ND means non detected

Columns with the same letter were not significantly differences $\mathrm{P}<0.05$ concentration levels of tetracycline residues of treated meat.

There are many factors affecting antibiotics residues in meat, one of them is the withdrawal time, other factors are the effects of chilling and cooking, freezing. Antibiotics are leached from the tissues in cooking juices, when evaluating the fate of antibiotic in minced beef during cooking, there was a $45 \%$ decrease of antibiotic in boiling, and a $50 \%$ decrease in frying (Rose et al, 2009).

The results of this study concluded that meat and offal from adult cattle, cow and imported meat had a considerable of tetracycline residues which dose not exceed the Egyptian permissible limits. Veterinarians must be well aware of the importance of drug residues in the meat and their possible risk to the general public. They must have updated information about the proper withdrawal times of all the drugs used in their areas of practice. Marinating and simmering technique were effective on reducing tetracycline concentrations levels in treated meat samples. 
Table (2) Effect of Marinating Technique on Concentrations Level of Tetracycline Residues in Meat

\begin{tabular}{|c|c|c|c|}
\hline Groups & Meat & Reduction \% & S.E. \\
\hline I I & $9.915^{\mathrm{b}}$ & 12.2 & 0.05 \\
\hline I I I & $12.527^{\mathrm{c}}$ & 45.1 & 0.14 \\
\hline IV & $7.615^{\mathrm{d}}$ & 11.4 & 0.01 \\
\hline
\end{tabular}

S.E. means Standard Error

Columns with the same letter were not significantly differences $\mathrm{P}<0.05$

Table (3) Effect of Simmering on Concentrations Level of Tetracycline Residues in Meat

\begin{tabular}{|l|l|l|c|}
\hline Groups & Meat & Reduction \% & S.E. \\
\hline I I & 24.894 & $8.484^{\mathrm{b}}$ & 0.12 \\
\hline I I I & 34.818 & $15.068^{\mathrm{c}}$ & 0.10 \\
\hline IV & 22.499 & $6.662^{\mathrm{b}}$ & 0.30 \\
\hline
\end{tabular}

S.E. means Standard Error

Columns with the same letter were not significantly differences $\mathrm{P}<0.05$

\section{References}

Abdul Salam, I.; Abdulkadir, J. amd Muhammad, G. (2010): Multiple antibiotic residues in meat from slaughtered cattle in Nigeria. The international journal of veterinary medicine ISSN: 19378165., 8 (1).

Addisalem, B.; Bayleygn, Z. and Bayleyegn, Z. (2012): Tetracycline residue levels in slaughtered beef cattle from three slaughterhouses in central Ethiopia. Global Veterinaria., 8(6): 546-554.

Al-Wabel, N. A. (2011): Monitoring of tetracycline residues in table eggs collected from Qassim region KSA. Journal of Agricultural and Veterinary Sciences. Qassim University., 4(2): 109-123.

Bala, A.; Junaidu, A.; Salihu, M.; Onifade, K.; Magaji, A.; Faleke, O.; Saulawa, M.; Musawa, A.;
Mohammed, M.; Muhammad, L.; Pewan, S.; Anzaku, S. and Emenna, P. (2012): Survey of lead residue in kidney and liver of slaughtered cattle in Sokoto central abattoir, Sokoto state, Nigeria. Journal Vet. Adv., 2(3): 132-138.

Basma, A. (2012): Studies on antibiotic residues in local and imported meat. Master thesis of Vet. Sci. Zag. Univ. Fac. Of Vet. Med., Egypt.

Bedada, A.; Zewde, B. and Zewde, B. (2012): Tetracycline residue levels in slaughtered beef cattle from three slaughterhouses in central Ethiopia. Global Veterineria 8(6): 546-554.

Dana, G.; Jhon, K.; Dale, A. and Pasloske, K. (2008): Hand book of veterinary drugs, $2^{\text {nd }}$ edition.

Egyptian Organization
Standardization (2010): Maximum 
level for certain contaminants in food stuffs. ES No. 7136/2010.

Eremong, D. (2011): Metal and nutrient composition of processed cattle hide (welle) using four procedures. Thesis submitted to the school of graduate studies, Knust in partial fulfillment of the requirement for the Master of Science (meat science) degree. Kwame Nkrumah Univ. of science and technology (Knust).

FAO (1999): Code of practice for forest harvesting in Asia-Pacific. RAP Publication 1999/12. Bangkok, FAO Regional Office for Asia and the Pacific (also available atwww.fao.org/docrep/004/ac142e/ ac142e00.htm).

Farag, H. (2002): Assessment of some heavy metals in the edible offal and public health significance. Ph.D thesis of Vet. Sci. Suez Canal Univ. Fac. Of Vet. Med., Egypt.

GraphPad Instant (2009): GraphPad Instant Software, Inc. All rights reserved. Use of this software is subject to the conditions contained on the accompanying Software License Agreement. InStat is a registered trademark of GraphPad Software Inc.

Heba, E. (2012): Quantitative and qualitative analysis to some antimicrobial in raw and prepared meat products. Master thesis of Vet. Sci. Zag. Univ. Fac. Of Vet. Med., Egypt.

Ibrahim, A.; Junaidu, A. and Garba M. (2010): Multiple antibiotic residues in meat from slaughtered cattle in Nigeria. The Internet Journal of Veterinary Medicine ISSN. 8(1): 1937-8165.

Joanne, C. (2012): "Marinating Meat Then Freezing It", "Epicurious", August, 2012.

Khalafalla, A.; Fatma, H.; Schwagele, F. and Mariam, A. (2011): Heavy metal residues in beef carcasses in Beni-Suef abattoir, Egypt. Veterinaria Italiana, 47(3): 351-361.

Kukanich, B.; Gehring, R.; Webb, A.; Craigmill, A. and Riviere, J. (2005): Effect of formulation and route of administration on tissue residues and withdrawal times. Journal Am. Vet. Med. Assoc., 227: 1574-1577.

Lama, A. M. (2010): Fate of oxytetracycline \& doxycycline in soil \& underground water. Master thesis of Science in Chemsitry. Faculty of Graduate Studies, at AnNajah national Univeristy, Nablus, Palestine.

Lei, T.; Tian, W.; He, L.; Huang, X.; Sun, Y.; Deng, Y.; Sun, Y.; Lv, D.; Wu, C.; Huang, L.; Shen, J. and Liu, J. (2010): Antimicrobial resistance in Echerichia coli isolates from food animals, animal food products and companion animals in China. Vet. Microbiol., 146(1-2): 85-89.

Levetzow R. and Wise H. (1979): Method Zum Nachwies Von Ruckstanden Antibacterial Wirksamer Sustanzen in Frischen Fleish, Insitute of Vet. Med. (meat Hygiene), Berlin. 
Olatoye, I. and Ehinmowo, A. (2010): Oxytetracycline residues in edible tissues of cattle slaughtered in Akure, Nigeria. Nigerian Vet. Journal 31(2): 93-102.

Olusola, A.; Diana, B. and Ayoade, O. (2013): Assessment of Tetracycline, Lead and Cadmium Residues in Frozen Chicken Vended in Lagos and Ibadan, Nigeria. Pakistan Journal of Biological Sciences, 15: 839-844. Rose, D.; Bygrave, J.; Farrington, W. and Shearer, G. (2009): The effect of cooking on veterinary drug residues in food: 4. Oxytetracycline. Food Additives Contaminants, 13(3).

Salehzadeh, F.; Salehzadeh, A.; Rokni, N. ; Madani, R. and Golchinefar, F. (2007): Enrofloxacine residue in chicken tissues from Tehran slaughterhouses in Iran. Pakistan Journal of nutrition, 6(4): 409-413.
Shareef, A.; Jamel, Z. and Yonis, K. (2009): Detection of antibiotic residues in stored poultry products. Iraqi Journal of Veterinary Science,23: Suppl.I,45-48.

Shirley, C. (2012): "Marinades Add Flavor but Don't Always Tenderize - Fine Cooking Recipes, Techniques and Tips". The Taunton Press Inc. Retrieved 28 November 2012.

Wikipedia, the free encyclopedia (2013): (Redirected from Marinating) Available on:"http://en.wikipedia.org/w/index. php?title=Marination\&oldid $=56698$ 1771. This page was last modified on 3 August 2013 at 12:53.

Xu, W.; Zhu, X.; Wang, L.; Deng, L. and Zhang, G. (2006): Residues of Enrofloxacin, flurazolidone and their metabolites in Nile tilapia (Oreochromis niloticus). Aqua., 254:

1-8. 


\section{الملخص العربي}

\section{استخدام بعض الوسائل التقليدية للسيطرة على متبقيات التتراسيلكين فى اللحوم

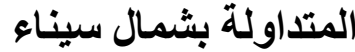

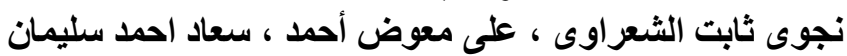

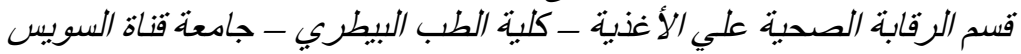

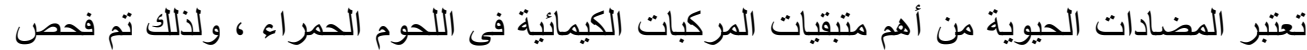

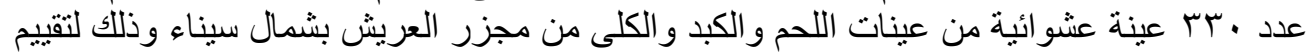

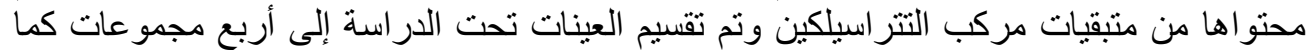

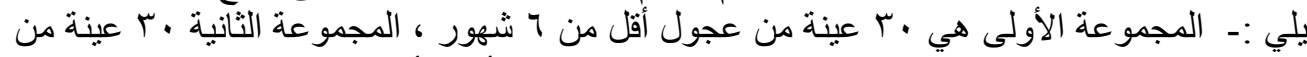

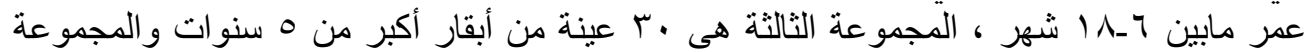

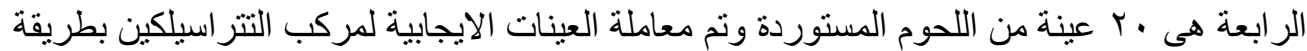

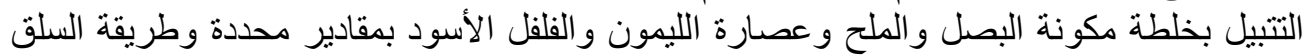

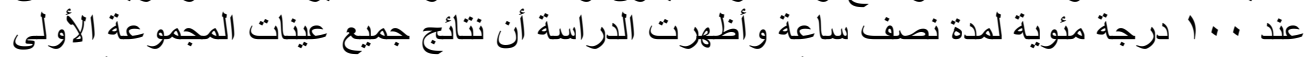

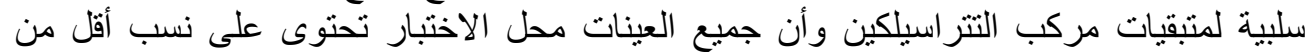

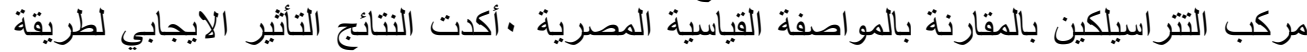

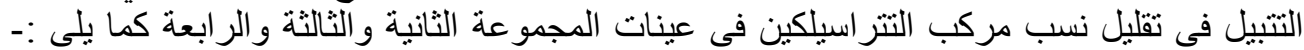

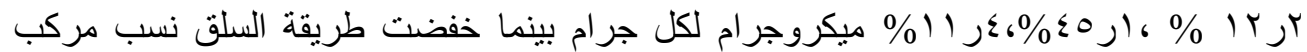

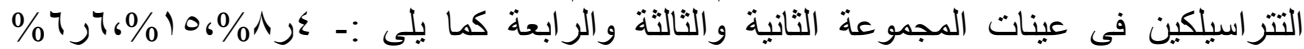

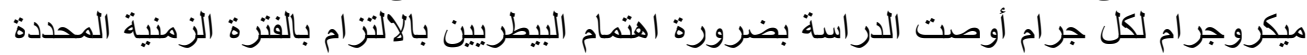

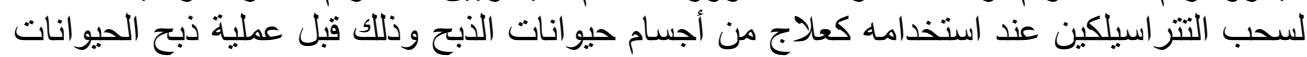

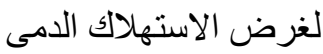

